\title{
Sources and dynamics of trace metals in an urban river under geogenic and anthropogenic influences: the Jalle River (Bordeaux Metropole, France)
}

\author{
ALEXANDRA COYNEL ${ }^{1}$, ANTOINE LERAT ${ }^{1}$ AND \\ ANTOINE MARACHE ${ }^{2}$ \\ ${ }^{1}$ Université de Bordeaux - UMR CNRS 5805 EPOC \\ ${ }^{2}$ Université de Bordeaux - UMR 5295 I2M \\ Presenting Author: alexandra.coynel@u-bordeaux.fr
}

The aquatic ecosytems of industrialized countries are confronted to different degrees by anthropogenic pressures that generate metal pollution, particularly in urban areas. This study is based on hydrogeochemical monitoring of trace metals (TMs), including Rare Earth Elements (REEs), $\mathrm{Al}$ and $\mathrm{Fe}$ in dissolved and particulate phases $(n=35)$ over a 2 year period at the outlet of the Jalle River $\left(330 \mathrm{~km}^{2}\right)$, that drains Bordeaux Metropole (France), discharging directly into the Gironde Estuary. This monitoring was supplemented by intermittent sampling on 4 sites to characterize the upstream catchment as well as effluents from a wastewater treatment plant (WWTP) and runoff from the outlet of the stormwater collector draining the Northern part of Bordeaux Highway (NBH). The objectives of this study were to analyze the spatio-temporal variability of concentrations, to identify controlling factors and to evaluate the contribution of different sources to the fluxes exported by the Jalle River. We demonstrated that the upstream watershed strongly influences the geochemical composition of the Jalle waters for many TMs (e.g. Al-Fe-REEs) and that it contributes the bulk of dissolved TM inputs (e.g. $>95 \%$ for $\mathrm{Al}$ and REEs except Gd [71\%]) excepting $\mathrm{Cu}_{\mathrm{d}}-\mathrm{Zn}_{\mathrm{d}}-\mathrm{Mo}_{\mathrm{d}}-\mathrm{Ag}_{\mathrm{d}}-\mathrm{Sn}_{\mathrm{d}}$. The effluents from the WWTP affect the quality of the Jalle waters by significantly increasing $\mathrm{Gd}_{d}-\mathrm{Cu}_{\mathrm{d}}-$ $\mathrm{Mo}_{\mathrm{d}}-\mathrm{Ag}_{\mathrm{d}}-\mathrm{Sn}_{\mathrm{d}}$ concentrations and by contributing between $25 \%$ (Gd) and $50 \%(\mathrm{Sn})$ to exported fluxes. The runoff from the NBH (excluding major storm events) influences the Jalle River only more intermittently with regard to $\mathrm{Sb}_{\mathrm{d}}-\mathrm{Cu}_{\mathrm{d}}-\mathrm{Zn}_{\mathrm{d}}$ concentrations and is thought to represent respectively 16, 24 and 34\% of input into the Jalle River. Anthropogenic loads does not seem to affect the particulate TM concentrations of the Jalle River, contrary to observations made during a major storm event analyzed with high temporal resolution. Such a difference could be explained by the sampling strategy put in place for this monitoring operation which i) would not take account of non-treated, bypass WWTP water discharge during major storm episodes, where the particulate TM removal are low and ii) would underestimate particulate emissions during storms which are mostly transmitted during the first flush of the event. 